\title{
Role of Yoga in Purifying Body
}

\author{
Ravi Kumar ${ }^{1 *}$
}

\section{ABSTRACT}

The purpose of this study is to explore the role of yoga in purifying body. Different practices of yoga like yama, niyama, asana, pranayama, pratyahara, dharana, dhyana and samadh purify the body through movements that enhance and improve the flow of blood, oxygen and life force energy in the tissues, muscles and organs. The present paper focuses on how pranayama purify the body.

Keywords: Physical Purification, Yama, Niyama, Asana, Pranayama, Pratyahara, Dharana, Dhyana and Samadh

Due to 500-year history behind Hatha yoga, an introductory stage of physical purification. It is used to stretch and strengthen the entire person with moving meditations to improve the body. Purification is an essential aim of all the yogic practices, and is the first principle of selfdiscipline (niyama) in Patanjali’s eight-limbed approach (Yama, niyama, asan, pranayama, pratyahara, dharana, dhyana, samadhi). The yogis have revealed that impurities in our internal body adversely affect our state of mind. Through the yogic practices of asana, pranayama, tapas and shatkarma, the body and the mind have become cleansed.The yoga poses compress and massage the muscles and organs to move out old stagnant blood and bring in fresh blood full of nutrients and oxygen. The breathing practices of pranayama purify the body through the balance and cultivation of energy throughout the entire body. Different pranayamas have different actions on the body and thus different purifying effects. Kapalabhati (breath of fire) is warming and energizing, purifying the body through the creation of heat and the movement of energy. Nadi Sodhana (alternate nostril breath) is calming and cleansing, purifying the body through reducing stress and removing blockages in the nadis (energy channels). While tapas creates a conflict between our will and the desire of our mind producing an internal "fire" which enlighten and burns up our mental and physical impurities. The six cleansing practices of shatkarma purify the body by physically removing excesses of mucus or phlegm. These are primarily unexplored practices that must be learned and performed under the supervision of a qualified teacher. The shatkarmas are described as six groups of yogic cleansing techniques: Neti: nasal cleaning and irrigation, Dhauti: cleansing of the digestive tract, Nauli: abdominal massage, Basti: colon

\footnotetext{
${ }^{1}$ Lecturer of Physical Education, Air Force School, Jammu

*Responding Author

(C) 2016 I R Kumar; licensee IJIP. This is an Open Access Research distributed under the terms of the Creative Commons Attribution License (http://creativecommons.org/licenses/by/2.0), which permits unrestricted use, distribution, and reproduction in any Medium, provided the original work is properly cited.
} 
cleaning, Kapalbhati: purification and vitalization of the brain, and Trataka: blinkless gazing. The goal of these practices is to purge out excesses in order to bring the physical elements into balance. When the body has been purified through the various practices of yoga, the overall result is an increase in the flow of prana through the entire body, improving our capacity to work, think, digest, taste, feel, and experience life. In simple words, we can say that when the body is physically healthy, focused and stress is under control.

There is growing evidence that yoga can have a significant effect on Physical purification. Yoga is an ancient art which helps to purify the physical health of a human being. In yoga, Pranayama helps to purify the impurities from the human body by following practices such as Kapalabhatti, bhastrika, nauli, jala neti and sutar neti (Ross and Thomas, 2010; Malhotra et al., 2004). In addition to suryanamaskar (sun salutation) is a very good aerobic exercise for kapha. It is also helpful in the treatment of obesity and depression. The suryanamaskar is an ideal asana for kapha, sun salutation is very active, creates heat, and opens the chest. Individuals can benefits from sun salutations during the time of day (Mark, 2010; Malhotra et al., 2004). Thus the aim of this study is to examine the role of yoga in purifying body.

The paper is structured as follows. After introduction, concept of yoga and physical purification. Next, we develop a conceptual framework illustrating the physical purification through yoga. The paper is concluded by highlighting yoga implications, limitations, and future research.

\section{Concept of yoga and physical purification \\ Yoga}

The term 'yoga' derived from sanskrit root 'yuj' which means "union". In the spiritual sense, yoga means union of the mind with the divine intelligence of the universe. In the views of Patanjali, who is supposed to be the founder of yoga, the meaning of the word 'yuj' is to stabilise the mind for the union of Atma and Parmamtma. In short we can say that yoga is a way to join god. In modern times yoga play a very important role in our life. Each individual run after money. Some of them keep busy themselves busy in unhealthy competition. Therefore Each individual must regular practices of yoga to make a happy life. yoga is very helpful to remove the tensions, make concentration, free from sufferings and improve the physical health. Moreover, it develops optimum level of health to lead happy an prosperous life (Ward et al., 2014). Yoga aims through its practices to liberate a human being from the conflicts of duality (body-mind), which exists in every living thing, and from the influences of gunas, the qualities of universal energy that are present in everything. In other words, one of the yoga practices, hatha yoga is based on the knowledge, development, and balance of psychophysical yoga. The three main elements used in hatha yoga to attain its purposes are the body, physical part of the man; the mind, the subtle part; and the element that relates the body with the mind in a special way, the breath (James and Raub., 2002). On the other hand, Yoga consists of eight stages (Yama, niyama, asan, pranayama, pratyahara, dharana, dhyana, samadhi) to achieve the union of Atma and Parmatma. 
Table 1: Categories of yoga

\begin{tabular}{|l|l|}
\hline Categories of yoga & Description \\
\hline Yama & $\begin{array}{l}\text { It is basic principles for the benefit of society such as honesty, } \\
\text { truthful, non-violence, non-steal and absence of lust (Giri, 2006) }\end{array}$ \\
\hline Niyam & $\begin{array}{l}\text { It is the basic principles for self like a healthy body, hygienic } \\
\text { habits, proper diet, sleep, rest, work routine, etc. (Babu, 2012) }\end{array}$ \\
\hline Asanas & $\begin{array}{l}\text { It is slow stretching activities performed to improve the whole } \\
\text { body fitness (Giri, 2006) }\end{array}$ \\
\hline Pranayam & $\begin{array}{l}\text { It is a systematic control of breathing performed to improve the } \\
\text { internal functioning of the whole body. (Malhotra et al., 2004) }\end{array}$ \\
\hline Pratyahara & $\begin{array}{l}\text { It develops the inner mental strength by controlling sense organs } \\
\text { (Mallison, 2004) }\end{array}$ \\
\hline Dharana & $\begin{array}{l}\text { It helps to fixing the concentration on single object i.e., } \\
\text { concentration (Giri, 2012) }\end{array}$ \\
\hline Smadhi & $\begin{array}{l}\text { It help to make a high level of concentration (James and Raub, } \\
\text { 2002) }\end{array}$ \\
\hline
\end{tabular}

The various categories of yoga are discussed in table 1 .

Table 2: Definitions of yoga

\begin{tabular}{|l|l|}
\hline Authors & Define \\
\hline Swami Digambar ji & "Yoga is a union of atma and parmatma" \\
\hline Satyapal & $\begin{array}{l}\text { "Yoga is derived from sanskrit word 'yuj' } \\
\text { which means the union of soul with god" }\end{array}$ \\
\hline Shankracharya & $\begin{array}{l}\text { "Yoga is withdrawal of senses organs from the } \\
\text { worldly objects and their control". }\end{array}$ \\
\hline
\end{tabular}

\section{Physical purification}

Pranayam

Pranayam can be considered as an breathing air as power of life. Pranayams are systematic rhythmic manage of breathing to provide deep effects over individual. Pranayams are also systematic activities in which inhale, exhale and holding of breath are controlled. There are numerous ways of Pranayams based on this technique of inhale, exhale, and holding of breathing include kapalbhati, bhastrika, nauli, jalaneti and sutar neti (Malhotra et al. , 2009).

\section{A) Kapalbhati pranayama}

Kapalbhati pranayama is an important kind of breathing exercise that helps to relieve of various ailments over a period of time. The word kapalbhati is composed of two words kapal and bhati. "Kapal" means skull (skull includes all organs under the skull too) and "bhati" means shining. Due to course of action, the organs under the skull mainly the brain and the small brain are 


\section{Role of Yoga in Purifying Body}

inclined in a good manner. Kapalbhati is done in a sitting posture (Panwar et al., 2012). In the words of Gherand samhita, Kapalbhati is deliberated mainly to the cleaning of other effects. The process of kapalbhati include short and strong forceful exhalations and inhalation happen automatically. Kapalbhati include vatakrama, vyutkrama, and sheetkrama kapalbhati.

1) Vatakrama kapalbhati:- It is similar to bhastrika, a mechanism of pranayama, expect that exhalation is active while inhalation is passive, the opposite of normal breathing.

2) Vyutkrama kapalbhati:- It is similar to jala neti, it includes sniffing water through the nostrils and letting it flow down into the mouth and then spitting it out.

3) Sheetkrama kapalbhati:- It is reversed of vyutkrama kapalbhati, in which water is taken through the mouth and then expelled through the nose.

In addition to patient's suffereing from heart trouble, lung trouble should practice this under an expert guidance. Each individual who are suffering from diseases of blood circulation should also perform the process under guidance and care of experts.

\section{B) Bhastrika pranayam}

The term bhastrika pranayam can be considered as increases the flow of air into the body to produce inner heat at the physical and subtle level. It is also known as bellows breathe. It is helpful to release toxins present in the body that are produced from excess of air, bile, and phlegm, relief in various throat inflammations, remove diseases of the nose and chest and eradicates ashtma etc., expand and fortifies our nervous system, burn fat and promote naturally weight loss. In addition to this pranayam is strictly prohibited for those who are suffering from heart problems and high blood pressure (Bhavanani et al., 2012).

\section{C) Jala neti}

The term jala neti literally means "water cleansing". Jala neti is performed as routinely as using a toothbrush. Jala neti is performed daily usually the first thing in the morning with other cleansing practices. Sometimes it is done more often such as the end of the day if you work or live in a dusty or polluted environment. When dealing with problem of congestion it can be peformed up to four times a day and has been shown up to speed the healing process for common colds (Shankarappa, 2012). In jala neti, the warm salty water flow through one side of the nasal cavity and out the other nostril. It is helpful to remove all dirt and bacteria filled mucus from within the nose. Jala neti is also helpful for headaches, epilepsy, depression and general mental tension. Neti is of great importance for problems related with the eyes. Neti is admirable for those who are trying to quit smoking (Bhavanani et al., 2012).

\section{D) Nauli}

Nauli can be considered as a yogic cleansing exercise or kriya. Nauli cleanses the internal organs and abdominal region such as side-to-side rolling motion of the abdominal muscles (Panwar et al., 2012). In other words we can say that this massage is great for your kidneys and liver, your 
bladder and your pancreas, gall bladder and reproductive organs. Nauli is also beneficial for those people who are suffering from diabetes. In the views of Brian Dana Akers "lower the shoulders. Revolve the stomach left and right with the speed of a strong whirlpool. This is called nauli by the masters. this nauli is the crown of hatha practices. Nauli encourages a weak gastric fire, restore the digestion, always bring happiness, and dries up all defects and diseases" (Malthotra et al., 2009). Nauli is also considered as an difficult exercise, which can be learned only perseverance and patience. Nauli is helpful for the recovery of constipation. The exercise may clean the small intestine and eliminate digesting problems. In addidition to nauli should not be performed by pregnant women or people with hypertension, heart diseases, or various gastrointestinal ailments.

\section{Conceptual framework}

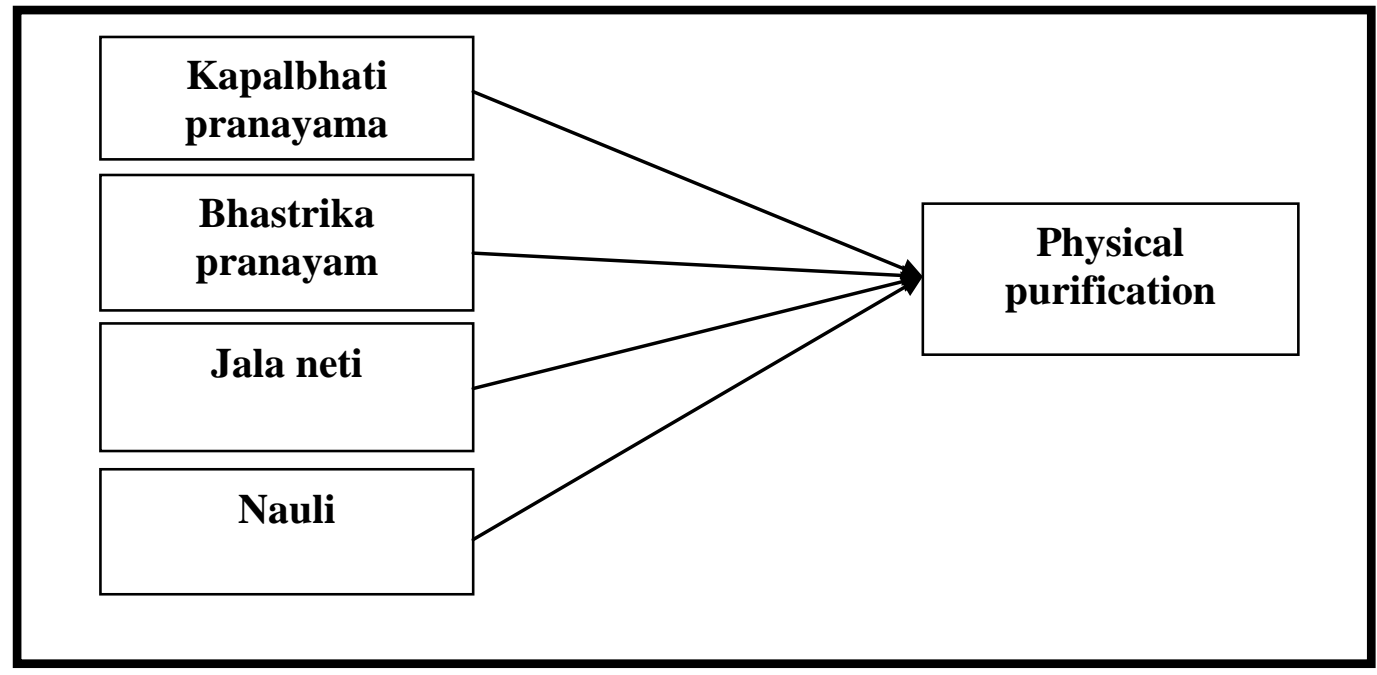

Figure 1. Physical purification through yoga

Figure 1 shows that with the help of yoga, body can be purified through pranayama such as kapalbhati, bhastrika pranayam, jala neti, and nauli as discussed earlier.

\section{Implications, Limitations and Future Research}

The paper conceptual in nature, contributes in an understanding the role of yoga in purifying body. Yoga can be considered as one of the significant aspects to purify the body of a human being. One of significant technique of yoga i.e. pranayam namely kapalbhati, bhastrika pranayam, jala neti, and nauli contribute to physical purification. The previous literature identified that the yoga can contribute to make a happier life to the extent that they impact on the physical fitness. The proposed framework can serve to guide empirical studies and to illuminate understanding of the role of yoga in purifying body.

Few limitations of this study need to be acknowledged. First, each practices of yoga cannot be performed by every individual. For instances bhastrika pranayam cannot be performed by heart problems and high blood pressure patients. Where as nauli should not be performed by pregnant 
women or people with hypertension, heart disease, or various gastrointestinal ailments. Second, Practices of yoga used for physical purification are limited. In future research other practices of yoga for physical purification can be considered such as ujayii pranayam, sitli pranayam, bhramanri pranayam. Lastly the paper is conceptual in nature and empirical studies should be done in future research.

\section{REFERENCES}

Babu, K. R. (2012). A comparative study of yogangas in hatha-yoga and patanjali yoga sutras. International Journal Of Multidisciplinary Educational Research, 1 (3), 71-78.

Bhavanani, A. B., Madanmohan., \& Sanjay, Z. (2012). Suryanadi pranayama (right unilateral nostril breathing) may be safe for hypertensives. Yoga and Physical Therapy, 2 (4), 1-3.

Giri, S. N. (2006). Foundations of yoga: Yama and niyama. The Journal of Yoga, 5 (1), 1-3.

James, A., \& Raub, M. S. (2002). Psychophysiologic effects of hatha yoga on musculoskeletal and cardiopulmonary function: A literature review. The Journal of Alternative and Complementary Medicine, 8 (6), 797-812.

Malhotra, V., Tandon, O. P., Patil, R., Sen, T. K., Lobo, S.W., Nagamma, T., Rahul, A., \& Choudhary, A. (2009). Suryanadi Anuloma Viloma Pranayama Modifies Autonomic Activity of Heart. The Journal of Yoga, 8 (1), 1-4.

Mallison, J. (2004). The Gehranda samhita (1st ed.). New York: Yoga Vidya

Malothra, V., Singh, S., Singh, K.P., Sharma, S. B., Madhu, S.v., Gupta, P., \& Tandon, O. P. (2004). Effects of yoga and pranayama in non-insulin dependent diabetes mellitus. Indian Journal of Traditional Knowledge, 3 (2), 162-167.

Mark, S. (2010). Teaching yoga: Essentials Foundations and techniques. California: North Atlantic.

Panwar, S., Chourishi, A., Makwana, J. (2012). Efect of pranayama (yoga) on pulmonary function test of young healthy students. International Journal of Pharma and Bio Sciences, 3 (4), 12-16.

Ross, A., \& Thomas, S. (2010) The health benefits of yoga and exercise: A review of comparison studies. Journal of Alternative and Complementary Medicine, 16 (1), 3-12.

Shankarappa, V., Prashanth, P., Annamalai, N., \& Malhotra, V. (2012). The short term effect of pranayama on the lung parameters. Journal of Clinical and Diagnostic Research, 6 (1), 2730.

Ward, L., Stebbings, S., Cherkin, D., \& Baxter, G D. (2014). Components and reporting of yoga interventions for musculoskeletal conditions: A systematic review of randomised controlled trials. Complementary Therapies in Medicines, in press (www.sciencedirect.com). 